\section{Models for technology}

Willem Hackmann

Innovation as a Social Process: Elihu Thomson and the Rise of General Electric, 1870-1900. By W. Bernard Carlson. Cambridge University Press: 1991. Pp. 377. $\$ 44.50, £ 35$.

AT first glance there are many parallels between the childhood and early adulthood of Elihu Thomson and those other heroic figures of American technology, Thomas Edison and Henry Ford. Like them, he came from a humble background (his parents were Scottish working-class immigrants) and he was forced to curtail his education in order to help support his family; but thanks to plenty of ambition and hard work, he overcame these limitations and became a successful inventor. Unlike Ford, he grew up in the heart of a bustling industrial city, Philadelphia, and unlike Edison, he received a thorough early education in science. Both of these aspects are considered to be significant by Bernard Carlson, who interweaves Thomson's personal history into the social and technical milieu of his times.

Thomson conformed to those other hallmarks of the late nineteenth-century technological innovator, having a passionate interest in mechanical devices and a way of learning about science through the building of such machines (an activity that according to Carlson leads to 'craft knowledge'). Indeed, a central theme of this book is the rise of late nineteenth-century technology through the interplay of scientific and craft knowledge. (It is a moot point whether this interplay is relevant in modern research and development.) Carlson attempts to establish the factors that made Thomson's activity so successful in both technological and business terms from 1870 to 1900 . That key period began with Thomson's graduation from the Philadelphia Central High School and the start of his career as a chemical analyst in an ironmaster's laboratory, and ended when the General Electric Company established its Research Laboratory and Thomson relinquished his position as chief innovator of the company. The phenomenal growth in American technology during this period is reflected in Thomson's life; he and the electrical industry grew and matured together.

With Edwin J. Houston, a teacher at the Central High School, Thomson established the Thomson-Houston Electric Light Company in Philadelphia to manufacture the arc-lighting system that they had invented. In 1880 , a new company was formed, the American Electric Company in New Britain, Connecticut, later renamed the Thomson-Houston NATURE · VOL 356 · 16 APRIL 1992
Electric Company of Lynn, Massachusetts. In contrast to the New Britain venture, the Lynn enterprise was a great success, largely owing to the vision of Charles A. Coffin, the vice-president of Thomson-Houston. Coffin's experience in the expanding shoe-industry of the 1870s had taught him important lessons that he could now apply to the rapidly changing electrical manufacturing industry. Initially, small arc-light systems were

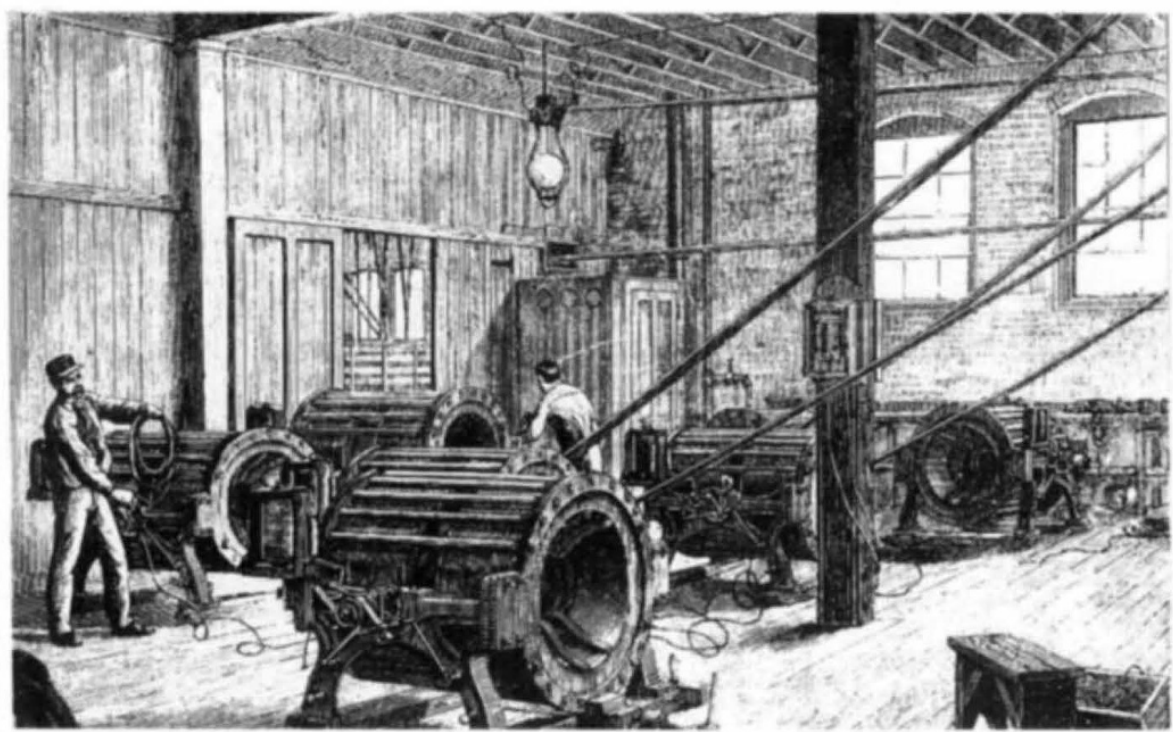

Dynamo-testing room in the Thomson-Houston factory at Lynn, Massachusetts (1985).

sold to individual users, but Coffin appreciated that the key to unlocking an enormous potential market for electric lighting was to promote central stations to be run by public utility companies. The new alternating-current technology that had been developed by Thomson, among others, made this concept possible. Thus, first Coffin learned how to create and sustain a large market for his product, and second he discovered that technology was not a static, but rather a dynamic, component of business strategy. Technology allowed costs to be reduced and could be used to capture new markets. The Thomson-Houston Company was successful in the electriclighting field because the firm managed to integrate technology, marketing strategy and business organization. These were also the years in which Thomson was at his most productive as an inventor. In 1892, the company merged with the Edison General Electric Company to form that powerful conglomerate, the General Electric Company. Thomson refused a directorship, but he continued to head product development in his "Model Room".

In addition to his initial dynamo (generator) and arc-light developments, Thomson invented an alternating-current motor, the first high-frequency generator and high-frequency transformer, the three-coil generator, electric welding by the incandescent method, a watt-hour meter, and an X-ray system with a double-focus tube. The third most prolific inventor in American history, his 696 patents have been surpassed in number only by Edison with 1,093 and by the railroad pioneer John O'Connor with 949. Thomson died in 1937, investigating scientific problems almost to the end.

Carlson has examined the broader issues of technical innovation as a social process by taking the life of Thomson as 